\title{
Comparing rapid micro-induction and standard induction of buprenorphine/naloxone for treatment of opioid use disorder: Protocol for an open-label, parallel-group, superiority, randomized controlled trial
}

\author{
Authors \\ James S.H. Wong, BSc1; \\ Mohammadali Nikoo, MD 1 ; \\ Jean N. Westenberg, BSc1; \\ Janet G. Suen, BSc1; \\ Jennifer Wong1; \\ Reinhard M. Krausz, MD, PhD, FRCPC1; \\ Christian G. Schütz, MD, PhD, MPH, FRCPC2; \\ Marc Vogel, PD Dr. med., MScPH3; \\ Jesse A. Sidhu, MD, MPH, FRCPC4; \\ Jessica Moe, MD, FRCPC, DABEM, MSc, MA5,6; \\ Shane Arishenkoff, MD, FRCPC7; \\ Donald Griesdale, MD, MPH, FRCPC8; \\ Nickie Mathew, MD, MSc, ABPN, FRCPC, ABPM4,9*; \\ Pouya Azar, MD, FRCPC, Dip. ABAM4* \\ *Dr. Azar and Dr. Mathew are co-senior authors.
}

\section{Affiliations}

1. Addictions and Concurrent Disorders Research Group, Institute of Mental Health, Department of Psychiatry, University of British Columbia, Vancouver, British Columbia, Canada

2. Behavioral Reward Affect + Impulsivity Neuroscience Lab, Institute of Mental Health, Department of Psychiatry, University of British Columbia, Vancouver, British Columbia, Canada

3. University of Basel Psychiatric Hospital, Division of Addictive Disorders, Wilhelm KleinStrasse 27, 4002, Basel, Switzerland

4. Department of Psychiatry, University of British Columbia \& Vancouver General Hospital, Vancouver, British Columbia, Canada

5. Department of Emergency Medicine, University of British Columbia \& Vancouver General Hospital, Vancouver, British Columbia, Canada

6. BC Centre for Disease Control, Provincial Health Services Authority, British Columbia, Canada

7. Department of Medicine, University of British Columbia \& Vancouver General Hospital, Vancouver, British Columbia, Canada

8. Department of Anesthesiology, Pharmacology and Therapeutics, University of British Columbia \& Vancouver General Hospital, Vancouver, British Columbia, Canada 9. BC Mental Health \& Substance Use Services, Provincial Health Services Authority, British Columbia, Canada 
medRxiv preprint doi: https://doi.org/10.1101/2020.05.22.20106062; this version posted May 26, 2020. The copyright holder for this preprint (which was not certified by peer review) is the author/funder, who has granted medRxiv a license to display the preprint in perpetuity.

All rights reserved. No reuse allowed without permission.

\section{Correspondence}

James Wong

Address: 430-5950, David Strangway Building, Department of Psychiatry, The University of British Columbia, Vancouver, British Columbia, V6T 1Z3, Canada.

Email: james.wong@ubc.ca 


\begin{abstract}
Background: Buprenorphine/naloxone (Suboxone) is a current first-line treatment for opioid use disorder (OUD). The standard induction method of buprenorphine/naloxone requires patients to be abstinent from opioids and therefore experience withdrawal symptoms prior to induction, which can be a barrier in starting treatment. Rapid micro-induction (micro-dosing) involves the administration of small, frequent does of buprenorphine/naloxone and removes the need for a period of withdrawal prior to the start of treatment. This study aims to compare the effectiveness and safety of rapid micro-induction versus standard induction of buprenorphine/naloxone in patients with OUD.

Methods: This is a randomized, open-label, two-arm, superiority, controlled trial comparing the safety and effectiveness of rapid micro-induction versus standard induction of buprenorphine/naloxone for the treatment of OUD. A total of 50 participants with OUD will be randomized at one Canadian hospital. The primary outcome is successful induction of buprenorphine/naloxone with low levels of withdrawal. Secondary outcomes are treatment retention, illicit drug use, self-reported drug use behaviour, craving, pain, physical health, safety, and client satisfaction.

Discussion: This is the first randomized controlled trial to compare the effectiveness and safety of rapid micro-induction versus standard induction of buprenorphine/naloxone. This study will thereby generate evidence for a novel induction method which eliminates substantial barriers to the use of buprenorphine/naloxone in the midst of the ongoing opioid crisis.
\end{abstract}

Clinical trial registration: NCT04234191

\title{
Keywords
}

micro-induction; microdosing; buprenorphine/naloxone; Suboxone; opioid agonist treatment; opioid use disorder 
medRxiv preprint doi: https://doi.org/10.1101/2020.05.22.20106062; this version posted May 26, 2020. The copyright holder for this preprint (which was not certified by peer review) is the author/funder, who has granted medRxiv a license to display the preprint in perpetuity.

All rights reserved. No reuse allowed without permission.

\section{Background}

The opioid crisis is one of the most serious public health issues in North America in recent years. In the United States, over 65,000 people died from using opioids in 2018, and in Canada, nearly 15,000 opioid-related deaths have occurred since 2016 1-3. Opioid-related deaths have surpassed motor vehicle incidents and homicide deaths combined, resulting in decreases in life expectancy in North America 1,4.

These deaths are primarily driven by untreated opioid use disorder (OUD), a common disorder affecting millions of individuals worldwide 5. Current North American guidelines strongly endorse opioid agonist treatment (OAT) with buprenorphine/naloxone as the first-line treatment of OUD, because of its superior safety profile and comparable efficacy over other forms of OAT 6,7. OAT is associated with reducing mortality, illicit drug use, and improving physical and mental health outcomes 8 .

Buprenorphine is a partial $\mu$-opioid receptor agonist. The partial agonism results in a ceiling effect on respiratory depression and lower risk for overdose 9. To prevent abuse and minimize diversion, buprenorphine is co-formulated with naloxone, an opioid antagonist, in a 4:1 ratio as buprenorphine/naloxone (brand name: SUBOXONE®) 10. When buprenorphine/naloxone is injected by individuals with OUD, naloxone precipitates withdrawal. When buprenorphine/naloxone is taken as prescribed, that is sublingually, naloxone is poorly absorbed and does not exert any significant clinical effect, leaving the opioid agonist effects of buprenorphine to predominate.

Buprenorphine exhibits a strong biding affinity to the $\mu$-opioid receptor 9 . When it is introduced in the presence of other opioids with weaker binding affinities, such as heroin, buprenorphine can precipitate withdrawal by displacing other opioids from the receptor. To avoid precipitated withdrawal, the standard method of induction of buprenorphine/naloxone requires patients to be abstinent from other opioids for a set period of time and thus requires patients to be in at least mild withdrawal before its administration 6,7. Standard buprenorphine/naloxone induction can thereby be very distressing and time-consuming for patients to tolerate, which can be a barrier for many patients who need this potentially life-saving therapy. Patients who experience significant levels of withdrawal or precipitated withdrawal during the induction process may also be less likely to be retained in treatment 11.

To overcome the difficulties of a standard induction method of buprenorphine, a novel induction method, known as micro-induction (also called micro-dosing), is being explored and increasingly employed by many clinicians in Canada, the United States, and other parts of the world 12-20. This induction method was first described as the 'Bernese Method' in a Swiss case series in 2016 13. The method involves administering buprenorphine at micro-doses once to twice daily, concurrently with the use of a full $\mu$-opioid receptor agonist, to avoid precipitated withdrawal. It did not require the two outpatients to go through withdrawal from opioids prior to induction, and they reached therapeutic doses in ten or more days.

Recently, our team developed a more rapid variation of micro-induction, known as 'rapid microinduction,' which was developed to be primarily used in an inpatient setting. It involves the 
medRxiv preprint doi: https://doi.org/10.1101/2020.05.22.20106062; this version posted May 26, 2020. The copyright holder for this preprint (which was not certified by peer review) is the author/funder, who has granted medRxiv a license to display the preprint in perpetuity.

All rights reserved. No reuse allowed without permission.

administration of buprenorphine/naloxone every three to four hours along with the use of a full $\mu$-opioid receptor agonist, resulting in patients reaching therapeutic doses in just three to five days 16. The rationale of this 'rapid' dosing is based on the hypothesis that buprenorphine reaches peak plasma concentration in approximately an hour 21. Rapid micro-induction offers several advantages over a standard induction method - eliminating the abstinence period preceding induction, reducing the risk of precipitated withdrawal, minimizing the symptoms of withdrawal and craving, potentially improving treatment retention, and reducing the time spent in hospital 16,18 .

Rapid micro-induction and variations of this novel induction method have been extensively described in several case reports and in a recent review, however, they have never been systematically evaluated in a clinical trial 12-20. To generate the evidence for this induction method in the midst of the ongoing opioid crisis, we propose the first randomized controlled trial was developed to compare the effectiveness and safety of rapid micro-induction versus standard induction of buprenorphine/naloxone.

\section{Study design}

\subsection{Overview of study design}

This study is a randomized controlled trial comparing the effectiveness and safety of rapid micro-induction versus standard induction of buprenorphine/naloxone. It has received approval from the Research Ethics Board of the University of British Columbia (H19-03254) and is registered in clinicaltrials.gov (NCT04234191). In this open-label superiority trial, eligible patients with OUD will be randomized to either: (a) the rapid micro-induction arm or (b) the standard induction arm (treatment as usual).

The study schema is presented in Figure 1. The study will take place at one site, Vancouver General Hospital (VGH) in Vancouver, British Columbia, Canada. The Complex Pain and Addiction Services (CPAS) is a consulting service in which VGH inpatients with substance use disorders are referred to for treatment and counselling. The study staff at CPAS will pre-screen referrals to determine general eligibility for participation in the study. Patients will then be invited by the study staff to complete the informed consent procedures. Once informed consent is provided, participants will undergo screening procedures to confirm their eligibility.

Eligible participants will be randomized on an allocation ratio of 1:1 to either of the two arms, using a blocked permuted block design with block sizes of 4 and 6 . Randomization will be managed with https://www.sealedenvelope.com. Once randomized, participants will complete baseline assessments and be followed for 7 days. Towards the end of the intervention period, the physician in charge will inform all participants about follow-up treatments that are available to them. Participants will receive follow-up with their community addictions physicians and/or the CPAS outpatient clinic. 


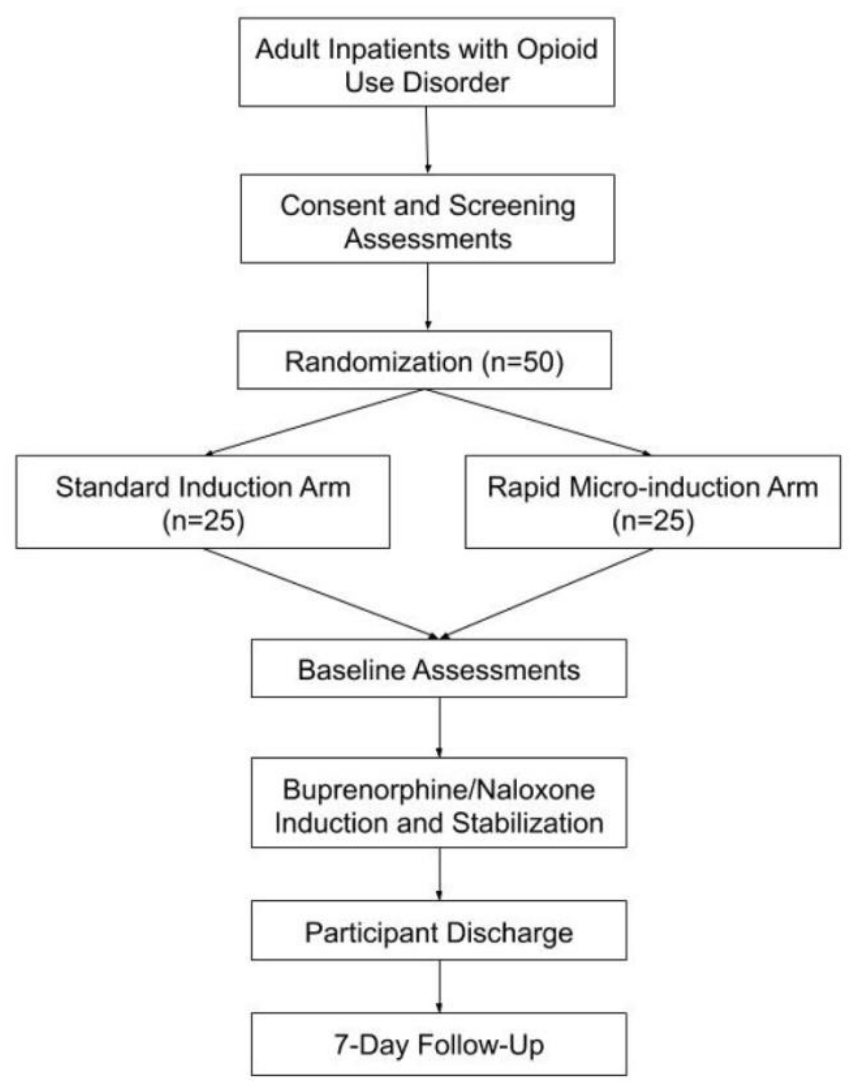

Figure 1. Study schema

\subsection{Study objectives}

The primary objective is to compare rapid micro-induction versus standard induction on the successful induction of buprenorphine/naloxone with low levels of withdrawal in patients with OUD. The secondary objectives are to evaluate treatment retention, illicit drug use, self-reported drug use behaviour, craving, pain, physical health, safety, and client satisfaction.

\subsection{Study population}

\section{Inclusion Criteria}

- Opioid use disorder as confirmed by DSM 5 diagnostic criteria

- Individuals seeking opioid agonist treatment (OAT)

- 19 years of age or older

- Willingness to comply with study procedures

- Provide written informed consent to participate in the study

- If female and of childbearing potential, agree to use an effective method of birth control approved by the study investigators throughout the study

\section{Exclusion Criteria}

- Diagnosis of severe medical or psychiatric conditions contraindicated for buprenorphine/naloxone and/or hydromorphone treatment 
medRxiv preprint doi: https://doi.org/10.1101/2020.05.22.20106062; this version posted May 26, 2020. The copyright holder for this preprint (which was not certified by peer review) is the author/funder, who has granted medRxiv a license to display the preprint in perpetuity.

All rights reserved. No reuse allowed without permission.

- Anticipated deterioration of health due to discontinuation of medications that are contraindicated with buprenorphine/naloxone and/or hydromorphone

- Positive pregnancy test for females of childbearing potential

- Not experiencing mild to moderate opioid withdrawal after the last dose of methadone

- Positive urine test for methadone

- Known allergy or sensitivity to buprenorphine/naloxone and/or hydromorphone

- Anticipation that the patient may need to initiate pharmacological treatment during the trial that is deemed unsafe by the study physician or could prevent study completion

- Unwilling or unable to use an effective method of birth control approved by the study investigators throughout the study

\section{Study treatments}

The rapid micro-induction arm will involve the administration of buprenorphine/naloxone and hydromorphone, while the standard induction arm will involve the administration of only buprenorphine/naloxone.

\subsection{Buprenorphine/naloxone}

Buprenorphine/naloxone (brand name: SUBOXONE®) is the recommended first-line option for the treatment of OUD in Canada and France, and an increasingly popular choice in a number of countries such as the United States and England 7,22-24. It will be administered in the form of a sublingual tablet.

\subsection{Hydromorphone}

Hydromorphone is an opioid medication used for managing pain, craving, and withdrawal in this study. The opioids the patients are using will be rotated to hydromorphone. Hydromorphone will be administered as needed to meet the patient's opioid requirements. It will be administered orally via tablet form; or administered intravenously, subcutaneously, or intramuscularly via liquid form. The route of administration will be determined by the physician in charge in consultation with the patient.

\subsection{Rapid micro-induction arm}

The titration schedule for the rapid micro-induction arm is described in Table 2. This titration schedule has also been termed as a '72-hour rapid micro-induction' because the induction is completed by the end of Day 3. Induction is considered to be completed when patients have received a total daily dose of $\geq 12 \mathrm{mg}$ of buprenorphine/naloxone, as $12 \mathrm{mg}$ is considered the minimum effective dose according to the product monograph of SUBOXONE® ${ }^{25}$. On the fourth (last) day of treatment, the dose is consolidated to once daily dosing. 
medRxiv preprint doi: https://doi.org/10.1101/2020.05.22.20106062; this version posted May 26, 2020. The copyright holder for this preprint (which was not certified by peer review) is the author/funder, who has granted medRxiv a license to display the preprint in perpetuity.

\subsection{Standard induction arm}

The standard induction titration schedule is described in Table 3. It has been written in accordance to the ASAM Practice Guidelines and the product monograph of SUBOXONE® sublingual tablet 6,25. Day 1 is initiated when participants score 11 or above on the Clinical Opiate Withdrawal Scale (COWS), and when they have been abstinent from short-acting opioids for at least 6-12 hours or from long-acting opioids for 24-72 hours. Induction is considered to be completed when patients have received a total daily dose of $\geq 12 \mathrm{mg}$ of buprenorphine/naloxone. On the third (last) day of treatment, the dose is consolidated to once daily dosing.

\begin{tabular}{|c|c|}
\hline & Buprenorphine/Naloxone* \\
\hline & \\
\hline $\begin{array}{l}\text { Day } 1 * * \\
(0 h-24 h)\end{array}$ & $\begin{array}{l}\text { Start with } 2 \text { to } 4 \mathrm{mg} \text { SL. } \\
\text { If } 60-90 \text { minutes have passed without the onset of withdrawal symptoms: } \\
\text { additional dosing can be done in increments of } 2 \text { to } 8 \mathrm{mg} \text { SL. } \\
\text { Suggested total dose target for Day } 1 \text { is } 8 \text { to } 12 \mathrm{mg} \mathrm{SL}\end{array}$ \\
\hline $\begin{array}{l}\text { Day } 2 \\
(24 h-48 h)\end{array}$ & $\begin{array}{l}\text { Start with dose equal to the total amount of buprenorphine/naloxone administered } \\
\text { on Day } 1 . \\
\text { Titrate in increments or decrements of } 2 \text { to } 8 \mathrm{mg} \text { to a level that holds the patient in } \\
\text { treatment and suppresses opioid withdrawal effects is guided by reassessment of } \\
\text { the clinical and psychological status of the patient. } \\
\text { Suggested total daily dose for Day } 2 \text { is } 12 \text { to } 16 \mathrm{mg} \text { SL. } \\
\text { Max total daily dose is } 24 \mathrm{mg} \text { SL. }\end{array}$ \\
\hline $\begin{array}{l}\text { Day } 3 \\
(48 h-72 h)\end{array}$ & $\begin{array}{l}\text { Consolidate Day } 2 \text { total dose to once daily dosing. } \\
\text { Suggested total daily dose for Day } 3 \text { is } 12 \text { to } 16 \mathrm{mg} \mathrm{SL} \text {. } \\
\text { Max total daily dose is } 24 \mathrm{mg} \text { SL. }\end{array}$ \\
\hline \multicolumn{2}{|c|}{$\begin{array}{l}\text { *Expressed as milligrams of buprenorphine in a buprenorphine/naloxone SL tablet } \\
* * \text { Day } 1 \text { is initiated when patient is COWS Score } \geq 11 \text {; and at least } 6-12 \text { hours after last use of } \\
\text { short-acting opioids or } 24-72 \text { hours after last use of long-acting opioids } \\
\text { SL, sublingual. COWS, Clinical Opiate Withdrawal Scale. }\end{array}$} \\
\hline
\end{tabular}

Table 3. Standard induction titration schedule 
medRxiv preprint doi: https://doi.org/10.1101/2020.05.22.20106062; this version posted May 26, 2020. The copyright holder for this preprint (which was not certified by peer review) is the author/funder, who has granted medRxiv a license to display the preprint in perpetuity.

All rights reserved. No reuse allowed without permission.

\subsection{Medical management}

In both the standard induction and rapid micro-induction arms, residual withdrawal symptoms will be managed as per ASAM guidelines: clonidine may be used at doses of $0.1-0.3 \mathrm{mg}$ every $6-8$ hours, with a maximum dose of $1.2 \mathrm{mg}$ daily (American Society of Addiction Medicine, 2020). Other non-narcotic medications targeting specific opioid withdrawal symptoms can also be used as per ASAM guidelines: benzodiazepines for anxiety, loperamide or bismuthsalycilate for diarrhea, acetaminophen or non-steroidal anti-inflammatory medications (NSAIDs) for pain, zopiclone for insomnia, and ondansetron for nausea.

All participants will receive routine motivational interviewing, behavioural-based psychoeducation, and supportive psychotherapy provided by the CPAS team based on the individual's need. The type, duration, and reason for all the psychological interventions and medications provided will be documented in the case report form (CRF).

\section{Outcomes and assessments}

The timeline of assessments is shown in Table 4. It should be noted that there is an additional day of assessments conducted with the experimental arm, because the experimental intervention (rapid micro-induction) takes one day longer than the treatment-as-usual intervention (standard induction).

\subsection{Primary outcome}

The primary outcome is successful induction of buprenorphine/naloxone with low levels of withdrawal. This is defined as the following: participants who remain in treatment until they have received a total daily dose of $\geq 12 \mathrm{mg}$ of buprenorphine/naloxone (successful induction), and score $\leq 12$ on the COWS (low levels of withdrawal) from the time of randomization to when they reach that dose 26. The COWS will be administered at baseline, days 1 to 4 of the experimental arm, and days 1 to 3 of the control arm - specifically, 10 to 30 minutes before each dose of buprenorphine/naloxone, and 30 minutes to 1 hour after each dose of buprenorphine/naloxone

\subsection{Secondary outcomes}

The secondary outcomes are treatment retention, illicit drug use, self-reported drug use behaviour, craving, pain, physical health, safety, and client satisfaction.

Treatment retention will be assessed by buprenorphine/naloxone prescription pick-up on day 7 .

Illicit drug use will be assessed by urine drug screens, which will analyze for the presence of cocaine, opioids including methadone, buprenorphine, hydromorphone, oxycodone, morphine, heroin, and fentanyl, benzodiazepines, amphetamines, and methamphetamine. Urine will be collected at screening, baseline, day 4 of the experimental arm, and day 3 of the control arm. 
medRxiv preprint doi: https://doi.org/10.1101/2020.05.22.20106062; this version posted May 26, 2020. The copyright holder for this preprint (which was not certified by peer review) is the author/funder, who has granted medRxiv a license to display the preprint in perpetuity.

All rights reserved. No reuse allowed without permission.

Self-reported drug use behaviour will be assessed by the Treatment Outcome Profile (TOP) at baseline, day 4 of the experimental arm, and day 3 of the control arm. The TOP is a 20-item instrument designed to assess and monitor substance misuse by measuring four different domains (substance use, health, crime and social functioning) and includes thirty-eight frequency, rating scale and period prevalence measure 27.

Craving and pain will be measured by visual analog scales (VAS) at baseline, days 1 to 4 of the experimental arm, and days 1 to 3 of the control arm. The VAS for craving and pain will be administered 10 to 30 minutes before each dose of buprenorphine/naloxone, and 30 minutes to 1 hour after each dose of buprenorphine/naloxone. The VAS presents the participant a rating scale which represents the spectrum of pain and craving: the left end indicates no pain or craving while the right end indicates extreme pain and craving. Participants mark the 10 centimeter rating scale at a location on along the spectrum which most accurately reflects the craving or pain they are experiencing 28 .

Physical health will be assessed by the health section of the Opiate Treatment Index (OTI) at baseline. The OTI is a structured interview designed to provide a measure of the effectiveness of drug treatments, by measuring six outcomes: drug use, HIV risk-taking behaviour, social functioning, criminality, health status, and psychological functioning 29. Only the health section of the OTI will be used; the health section is composed of items addressing signs and symptoms in major organ systems and injection-related health problems.

Safety will be assessed by the appearance of adverse events (AEs) and serious adverse events (SAEs), which will be recorded on the CRF. AEs and SAEs are defined in Section 6.1 Safety.

Client satisfaction will be assessed by the Treatment Perceptions Questionnaire (TPQ) on day 4 of the experimental arm and day 3 of the control arm. The TPQ is a 10-item scale which assesses the satisfaction of patients in addiction treatment program, examining two areas: perception of clients towards the nature and extent of their contact with the program staff ( 5 items), and aspects of the treatment service and its operation and rules and regulation (5 items) 30. 
medRxiv preprint doi: https://doi.org/10.1101/2020.05.22.20106062; this version posted May 26, 2020. The copyright holder for this preprint (which was not certified by peer review) is the author/funder, who has granted medRxiv a license to display the preprint in perpetuity. All rights reserved. No reuse allowed without permission.

\begin{tabular}{|c|c|c|c|c|c|c|c|c|}
\hline Assesments & Screening & Randomization & Baselines & Day 15 & Day 2 & Day 3 & Day 4 & Day 7 \\
\hline \multicolumn{9}{|l|}{$\begin{array}{l}\text { Experimental Arm: Rapid Micro- } \\
\text { Induction }\end{array}$} \\
\hline $\begin{array}{l}\text { (E stands for experimental arm } \\
\text { assessments) }\end{array}$ & & & & & & & & \\
\hline \multicolumn{9}{|l|}{ Control Arm: Standard induction } \\
\hline $\begin{array}{l}\text { (C stands for control arm } \\
\text { assessments) }\end{array}$ & & & & & & & & \\
\hline Informed consent form & $\begin{array}{l}\mathrm{E} \\
\mathrm{C}\end{array}$ & & & & & & & \\
\hline Physical examination & $\begin{array}{l}\mathrm{E} \\
\mathrm{C}\end{array}$ & & $\begin{array}{l}\mathrm{E} \\
\mathrm{C}\end{array}$ & $\begin{array}{l}\mathrm{E} \\
\mathrm{C}\end{array}$ & $\begin{array}{l}\mathrm{E} \\
\mathrm{C}\end{array}$ & $\begin{array}{l}\mathrm{E} \\
\mathrm{C}\end{array}$ & $\mathrm{E}$ & \\
\hline Medical history & $\begin{array}{l}\mathrm{E} \\
\mathrm{C}\end{array}$ & & & & & & & \\
\hline Pregnancy test & $\begin{array}{l}\mathrm{E} \\
\mathrm{C}\end{array}$ & & & & & & & \\
\hline Blood tests1 & $\begin{array}{l}\mathrm{E} \\
\mathrm{C}\end{array}$ & & & & & & & \\
\hline Viral profile 2 & $\begin{array}{l}\mathrm{E} \\
\mathrm{C}\end{array}$ & & & & & & & \\
\hline Urine drug screens & $\begin{array}{l}\mathrm{E}_{3} \\
\mathrm{C}_{3}\end{array}$ & & $\begin{array}{l}\mathrm{E}_{3} \\
\mathrm{C}_{3}\end{array}$ & & & $\mathrm{C}$ & $\mathrm{E}$ & \\
\hline $\begin{array}{l}\text { Opiate Treatment Index (OTI) - } \\
\text { Health Section }\end{array}$ & & & $\begin{array}{l}\mathrm{E} \\
\mathrm{C}\end{array}$ & & & & & \\
\hline Treatment Outcomes Profile (TOP) & & & $\begin{array}{l}\mathrm{E} \\
\mathrm{C}\end{array}$ & & & $\mathrm{C}$ & $\mathrm{E}$ & \\
\hline $\begin{array}{l}\text { Clinical Opiate Withdrawal Scale } \\
\text { (COWS) }\end{array}$ & & & $\begin{array}{l}\mathrm{E} \\
\mathrm{C}\end{array}$ & $\begin{array}{l}\mathrm{E}_{4} \\
\mathrm{C}_{4}\end{array}$ & $\begin{array}{l}\mathrm{E}_{4} \\
\mathrm{C}_{4}\end{array}$ & $\begin{array}{l}\mathrm{E}_{4} \\
\mathrm{C}_{4}\end{array}$ & $\mathrm{E}_{4}$ & \\
\hline Visual Analog Scale for Craving & & & $\begin{array}{l}\mathrm{E} \\
\mathrm{C}\end{array}$ & $\begin{array}{l}\mathrm{E}_{4} \\
\mathrm{C}_{4}\end{array}$ & $\begin{array}{l}\mathrm{E}_{4} \\
\mathrm{C}_{4}\end{array}$ & $\begin{array}{l}\mathrm{E}_{4} \\
\mathrm{C}_{4}\end{array}$ & $\mathrm{E}_{4}$ & \\
\hline Visual Analog Scale for Pain & & & $\begin{array}{l}\mathrm{E} \\
\mathrm{C}\end{array}$ & $\begin{array}{l}\mathrm{E}_{4} \\
\mathrm{C}_{4}\end{array}$ & $\begin{array}{l}\mathrm{E}_{4} \\
\mathrm{C}_{4}\end{array}$ & $\begin{array}{l}\mathrm{E}_{4} \\
\mathrm{C}_{4}\end{array}$ & $\mathrm{E}_{4}$ & \\
\hline $\begin{array}{l}\text { Treatment Perceptions } \\
\text { Questionnaire (TPQ) }\end{array}$ & & & & & & $\mathrm{C}$ & E & \\
\hline Assessment of Treatment Retention & & & & & & & & $\begin{array}{l}\mathrm{E} \\
\mathrm{C}\end{array}$ \\
\hline Adverse Event Report Form & & & $\begin{array}{l}\mathrm{E} \\
\mathrm{C}\end{array}$ & $\begin{array}{l}\mathrm{E} \\
\mathrm{C}\end{array}$ & $\begin{array}{l}\mathrm{E} \\
\mathrm{C}\end{array}$ & $\begin{array}{l}\mathrm{E} \\
\mathrm{C}\end{array}$ & $\mathrm{E}$ & \\
\hline
\end{tabular}

1Hemoglobin, fasting blood sugar, liver function test (ALT, AST, Bilirubin (direct and indirect), albumin, total protein), renal function test (BUN, creatinine), lipid profile (LDL, HDL, Cholesterol, Triglyceride) 
medRxiv preprint doi: https://doi.org/10.1101/2020.05.22.20106062; this version posted May 26, 2020. The copyright holder for this preprint (which was not certified by peer review) is the author/funder, who has granted medRxiv a license to display the preprint in perpetuity.

All rights reserved. No reuse allowed without permission.

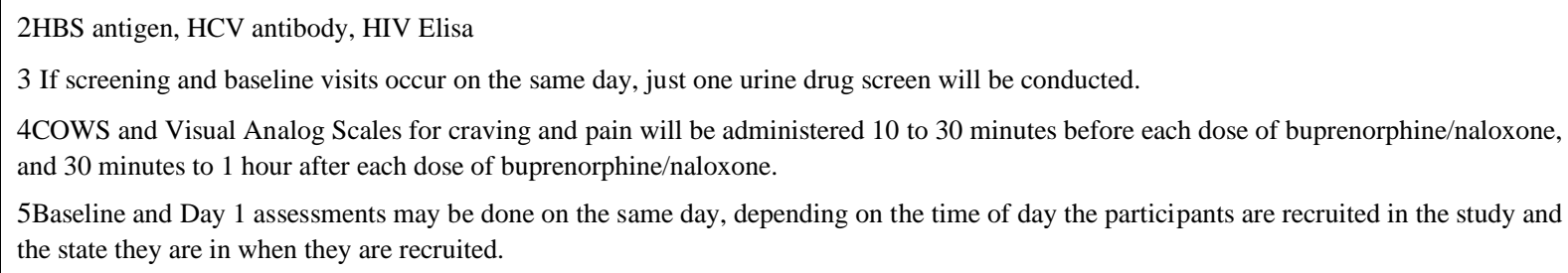

Table 4. Timeline of assessments

\section{Sample size and power calculation}

The sample size calculation for the binary primary outcome is based on testing for superiority in a parallel group clinical trial. As only case reports have been published on rapid micro-induction, we expect a success rate of $95 \%$ in the experimental arm based on the opinion of two addiction psychiatry experts familiar with the method. We expect a success rate of $10 \%$ in the control arm, as most participants in the arm are anticipated to experience moderate to higher levels of withdrawal, which is defined as having a COWS score of $\geq 13$. A difference of such a magnitude, $85 \%$, is deemed clinically meaningful. Using $\mathrm{G}^{*}$ Power 3.1 software, the minimum required sample size to power a Fisher's exact test to detect this difference between the two arms with a type I error of 0.05 and a type II error of 0.1 will be 12 (6 in each arm). Adjusting for an attrition rate of $10 \%$ (participants with incomplete COWS data, participants who have discontinued the treatment they were randomized, and participants who have discontinued both treatment and data collection procedures), the required sample size is 14 . We aim for a sample size of 50 (25 each arm), as a larger sample size is not feasible due to cost and constraints.

\section{Safety, treatment discontinuation, and study discontinuation}

\subsection{Safety}

Safety will be assessed by the appearance of adverse events (AEs) and serious adverse events (SAEs). AEs and SAEs will be monitored throughout the study. An AE is defined as any untoward medical occurrence in a participant, administered a study intervention, which does not necessarily have a causal relationship with this intervention. A SAE is defined as any untoward medical occurrence meeting one of the following criteria at any dose: results in death, is lifethreatening, requires inpatient hospitalization or prolongation of existing hospitalization, results in persistent or significant disability or incapacity, or is a congenital anomaly or birth defect. All AEs and SAEs will be documented accordingly on the adverse event report form, and will be reported to the clinical trial's Data Safety and Monitoring Board (DSMB). All SAEs will be reported to the Sponsor-Investigator and Health Canada.

\subsection{Treatment discontinuation and study discontinuation}

Participants are free to discontinue the treatment arm they were randomized to (treatment discontinuation), or the treatment they were randomized to and any data collection procedures (study discontinuation). Discontinuation may occur at any time without participants having to provide any reason and without prejudice to their medical care. Discontinuation from treatment or study may occur in the following circumstances, but not limited to: participant's request, 
medRxiv preprint doi: https://doi.org/10.1101/2020.05.22.20106062; this version posted May 26, 2020. The copyright holder for this preprint (which was not certified by peer review) is the author/funder, who has granted medRxiv a license to display the preprint in perpetuity.

All rights reserved. No reuse allowed without permission.

severe adverse reactions/events and/or other safety reasons, violence against treatment team without convincing evidence of mental illness like psychosis or delirium, and criminal behaviour with resulting imprisonment during the study period. All discontinuations from treatment or study will be documented on the CRF. Such participants will be considered failures of the primary outcome.

If participants discontinue the treatment they were randomized to (treatment discontinuation), they will be offered the other parallel treatment. This will be determined by the physician in charge in consultation with the patient. In order to reduce the amount of missing or incomplete data from such participants, research staff will continue to collect data from the participants if they allow them to do so.

If participants discontinue from the study (study discontinuation), the research staff will not collect data from them, and CPAS physicians will follow-up with appropriate treatment options.

\section{Data analysis}

All analyses will be conducted with both intention-to-treat (ITT) and per-protocol (PP) methods. Participants who discontinue the treatment arm they were randomized to (includes switches to the other arm) will be considered as failures of the primary outcome.

\subsection{Primary outcome}

The primary outcome will be assessed in a binary fashion: participants need to fulfill both criteria (successful induction and low levels of withdrawal) in order to be successful with the primary outcome. Outlier COWS scores will be checked and confirmed with the clinical records on an ongoing basis by the study coordinator. Effort will be made by the study team to avoid missing COWS scores during the study. In case of missing scores, multiple imputation will be used to impute the missing variables, and sensitivity analysis will be performed by once assigning failure to all the missing COWS score and then success to them, then describing and explaining the impact on the results. Fisher's exact test will be used to compare two groups with a significance level set at 0.05 . To demonstrate the effect size, we will use both unadjusted and adjusted odds ratios with $95 \%$ confidence intervals using logistic regression. In the latter, effect size will be adjusted for age, gender, and baseline COWS score in addition to allocated arm. Adjustment for baseline covariates will improve the sensitivity of the comparison.

\subsection{Secondary outcomes}

Secondary outcomes will be compared between two arms using Fisher's exact, Wilcoxon-Mann Whitney, and interaction terms from Linear Mixed Models for binary, interval, and repeated measures, respectively.

\section{Current status of the study}

As of February 2020, the study has received approval from the Ethics Board of the University of British Columbia and Health Canada to use buprenorphine/naloxone off-label in the trial. The study site, the Complex Pain and Addiction Services (CPAS) at Vancouver General Hospital (VGH) in Vancouver, British Columbia, Canada, has been preparing for recruitment. As per 
medRxiv preprint doi: https://doi.org/10.1101/2020.05.22.20106062; this version posted May 26, 2020. The copyright holder for this preprint (which was not certified by peer review) is the author/funder, who has granted medRxiv a license to display the preprint in perpetuity.

All rights reserved. No reuse allowed without permission.

discussion with experts working with CPAS, it is estimated that the recruitment rate will be 12 participants per month.

\section{Discussion}

This is the first study to compare the safety and effectiveness of rapid micro-induction and standard induction of buprenorphine/naloxone for the treatment of OUD. This study was initiated in response to the lack of research evaluating novel buprenorphine/naloxone induction protocols. While buprenorphine/naloxone has been widely accepted as a treatment method for OUD due to its superior safety profile compared to other OAT options, there are still several barriers that have prevented its widespread use. One major barrier is that the standard induction of buprenorphine/naloxone requires patients to be in a period of opioid withdrawal prior to starting treatment. Patients may be fearful of experiencing withdrawal associated with the standard induction protocol, which in turn may affect their retention in treatment 11 . This may also lead patients to try other forms of OAT with less favourable safety profiles, such as methadone and slow-release morphine 7. Thereby, ensuring a safer and more comfortable induction process for patients may improve treatment retention and decrease their risk of overdose.

The use of alternative induction protocols, such as rapid micro-induction, have consequently been utilized to address the concerns with the standard induction process.

Buprenorphine/naloxone rapid micro-induction confers many benefits over a standard induction method, as it can minimize withdrawal and craving symptoms, reduce the risk of precipitated withdrawal, and length of induction 16,18. Anecdotally and according to recent case reports and a review, clinicians have had much success with rapid-micro-induction, and the method has entered routine practice at some hospitals and clinics across Canada, the United States, and Europe 12-20.

The open-label design of this clinical trial may introduce the risk of potential bias. However, it is not feasible to blind participants or researchers due to the nature of the interventions. The study may also benefit from a large sample size and a longer duration of follow-up, but such changes are not possible due to resource and cost constraints. Despite these limitations, the evaluation of the primary and secondary outcomes will greatly contribute to our understanding of rapid microinduction. As the opioid crisis in North America continues, the results derived from this clinical trial will generate the first major body of clinical evidence on the effectiveness and safety of rapid micro-induction, a novel and patient-centered induction approach which could immensely improve the accessibility of buprenorphine/naloxone for patients with OUD.

\section{Conflicts of interest}

All authors declare no competing interests.

\section{Acknowledgements}

We thank Ehsan Moazen-Zadeh (Icahn School of Medicine at Mount Sinai), Fiona Choi (University of British Columbia), Mostafa Mamdouh (University of British Columbia), Kimia 
medRxiv preprint doi: https://doi.org/10.1101/2020.05.22.20106062; this version posted May 26, 2020. The copyright holder for this preprint (which was not certified by peer review) is the author/funder, who has granted medRxiv a license to display the preprint in perpetuity.

All rights reserved. No reuse allowed without permission.

Ziafat (University of British Columbia), and Kiana Kianpoor (University of British Columbia) for helpful discussions.

\section{Funding}

This work was supported by the Vancouver General Hospital \& UBC Hospital Foundation. MN is supported by Frederick Banting and Charles Best Canada Graduate Scholarships (Funding Reference Number $=157934$ ).

\section{References}

1. Hall WD, Farrell M. Reducing the opioid overdose death toll in North America. PLoS Med. 2018;15(7):e1002626-e1002626. doi:10.1371/journal.pmed.1002626

2. Ottawa: Public Health Agency of Canada. Opioid-Related Harms in Canada.; 2020. https://health-infobase.canada.ca/substance-related-harms/opioids.

3. Krausz MR, Wong JSH, Moazen-Zadeh E, Jang KL. Been There, Done That: Lessons from Vancouver's Efforts to Stem the Tide of Overdose Deaths. Can J Psychiatry. March 2020:0706743720912860. doi:10.1177/0706743720912860

4. Ye X, Sutherland J, Henry B, Tyndall M, Kendall PRW. At-a-glance - Impact of drug overdose-related deaths on life expectancy at birth in British Columbia TT - Aperçu Impact des décès par surdose de drogue sur l'espérance de vie à la naissance en ColombieBritannique. Heal Promot chronic Dis Prev Canada Res policy Pract. 2018;38(6):248251. doi:10.24095/hpcdp.38.6.05

5. Degenhardt L, Charlson F, Ferrari A, et al. The global burden of disease attributable to alcohol and drug use in 195 countries and territories, 1990\&\#x2013;2016: a systematic analysis for the Global Burden of Disease Study 2016. The Lancet Psychiatry. 2018;5(12):987-1012. doi:10.1016/S2215-0366(18)30337-7

6. American Society of Addiction Medicine. The ASAM National Practice Guideline for the Treatment of Opioid Use Disorder: 2020 Focused Update. J Addict Med. 2020;14(2S). https://journals.lww.com/journaladdictionmedicine/Fulltext/2020/04001/The_ASAM_Nati onal_Practice_Guideline_for_the.1.aspx.

7. Bruneau J, Ahamad K, Goyer M-È, et al. Management of opioid use disorders: a national clinical practice guideline. Cmaj. 2018;190(9):E247-E257.

8. Mattick RP, Breen C, Kimber J, Davoli M. Buprenorphine maintenance versus placebo or methadone maintenance for opioid dependence. Cochrane Database Syst Rev. 2014;(2). doi:10.1002/14651858.CD002207.pub4

9. Whelan PJ, Remski K. Buprenorphine vs methadone treatment: A review of evidence in both developed and developing worlds. J Neurosci Rural Pract. 2012;3(1):45-50. doi:10.4103/0976-3147.91934

10. Orman JS, Keating GM. Buprenorphine/Naloxone. Drugs. 2009;69(5):577-607. doi:10.2165/00003495-200969050-00006

11. Mattick RP, Ali R, White JM, O’Brien S, Wolk S, Danz C. Buprenorphine versus methadone maintenance therapy: a randomized double-blind trial with 405 opioiddependent patients. Addiction. 2003;98(4):441-452. doi:10.1046/j.13600443.2003.00335.x

12. Azar P, Wong JSH, Jassemi S, et al. A Case Report: Rapid Micro-Induction of 
medRxiv preprint doi: https://doi.org/10.1101/2020.05.22.20106062; this version posted May 26, 2020. The copyright holder for this preprint (which was not certified by peer review) is the author/funder, who has granted medRxiv a license to display the preprint in perpetuity.

All rights reserved. No reuse allowed without permission.

Buprenorphine/Naloxone to Administer Buprenorphine Extended-Release in an Adolescent With Severe Opioid Use Disorder. Am J Addict. 2020;n/a(n/a). doi:10.1111/ajad.13050

13. Hämmig R, Kemter A, Strasser J, et al. Use of microdoses for induction of buprenorphine treatment with overlapping full opioid agonist use: the Bernese method. Subst Abuse Rehabil. 2016;7:99-105. doi:10.2147/SAR.S109919

14. Lee DS, Hann JE, Klaire SS, Nikoo M, Negraeff MD, Rezazadeh-Azar P. Rapid Induction of Buprenorphine/Naloxone for Chronic Pain Using a Microdosing Regimen: A Case Report. A\&A Pract. 2020;14(2):44-47.

15. Randhawa PA, Brar R, Nolan S. Buprenorphine-naloxone "microdosing": an alternative induction approach for the treatment of opioid use disorder in the wake of North America's increasingly potent illicit drug market. C Can Med Assoc J. 2020;192(3):E73.

16. Klaire S, Zivanovic R, Barbic SP, Sandhu R, Mathew N, Azar P. Rapid micro-induction of buprenorphine/naloxone for opioid use disorder in an inpatient setting: a case series. Am J Addict. 2019;28(4):262-265.

17. Rozylo J, Mitchell K, Nikoo M, et al. Case report: Successful induction of buprenorphine/naloxone using a microdosing schedule and assertive outreach. Addict Sci Clin Pract. 2020;15(1):1-6.

18. Ghosh SM, Klaire S, Tanguay R, Manek M, Azar P. A Review of Novel Methods To Support The Transition From Methadone and Other Full Agonist Opioids To Buprenorphine/Naloxone Sublingual In Both Community and Acute Care Settings. Can J Addict. 2019;10(4):41-50.

19. Martin L, Lennox R, Regenstreif L, O’Shea T. Case Report:“Striving to Skip the Withdrawal" Using Buprenorphine-Naloxone Microdosing for Hospitalized Patients. Can J Addict. 2019;10(4):35-40.

20. Sandhu R, Zivanovic R, Klaire S, Nikoo M, Rozylo J, Azar P. Buprenorphine/naloxone induction for treatment of acute on chronic pain using a micro-dosing regimen: a case report. Can J Pain. 2019;3(1):79-84.

21. Chiang CN, Hawks RL. Pharmacokinetics of the combination tablet of buprenorphine and naloxone. Drug Alcohol Depend. 2003;70(2, Supplement):S39-S47.

doi:https://doi.org/10.1016/S0376-8716(03)00058-9

22. Olfson M, Zhang V (Shu), Schoenbaum M, King M. Trends in Buprenorphine Treatment in the United States, 2009-2018. JAMA. 2020;323(3):276-277.

doi:10.1001/jama.2019.18913

23. De Wet CJ, Reed LJ, Bearn J. The rise of buprenorphine prescribing in England: analysis of NHS regional data, 2001-03. Addiction. 2005;100(4):495-499. doi:10.1111/j.13600443.2005.01039.x

24. Benyamina A. The current status of opioid maintenance treatment in France: a survey of physicians, patients, and out-of-treatment opioid users. Int J Gen Med. 2014;7:449-457. doi:10.2147/IJGM.S61014

25. Indivior UK Limited. SUBOXONE® (Buprenorphine and Naloxone) Product Monograph. Berkshire; 2007.

26. Wesson DR, Ling W. The clinical opiate withdrawal scale (COWS). J Psychoactive Drugs. 2003;35(2):253-259.

27. Marsden J, Farrell M, Bradbury C, et al. Development of the treatment outcomes profile. Addiction. 2008;103(9):1450-1460. doi:10.1111/j.1360-0443.2008.02284.X 
medRxiv preprint doi: https://doi.org/10.1101/2020.05.22.20106062; this version posted May 26, 2020. The copyright holder for this preprint

(which was not certified by peer review) is the author/funder, who has granted medRxiv a license to display the preprint in perpetuity.

All rights reserved. No reuse allowed without permission.

28. McCormack HM, David J de L, Sheather S. Clinical applications of visual analogue scales: a critical review. Psychol Med. 1988;18(4):1007-1019.

29. Darke S, Ward J, Hall W, Heather N, Wodak A. The Opiate Treatment Index (Oti) Manual. Technical Report 11). Sydney, Australia: National Drug and Alcohol Research ...; 1991.

30. Marsden J, Stewart D, Gossop M, et al. Assessing Client Satisfaction with Treatment for Substance Use Problems and the Development of the Treatment Perceptions Questionnaire (TPQ). Addict Res. 2000;8(5):455-470. doi:10.3109/16066350009005590 